\title{
STEEL WELDABILITY INVESTIGATION BY SINGLE AND DOUBLE-PASS WELD THERMAL CYCLE SIMULATION
}

\author{
Dunder, M. ; Samardzic, I. ${ }^{* *}$; Simunovic, G. ${ }^{* *} \&$ Konjatic, P. ${ }^{* *}$ \\ * University of Rijeka, Department of Polytechnics, Sveucilisna avenija 4, 51000 Rijeka, Croatia \\ **: Josip Juraj Strossmayer University of Osijek, Mechanical Engineering Faculty, \\ Trg Ivane Brlic Mazuranic 2, 35000 Slavonski Brod, Croatia \\ E-Mail: marko.dundjer@uniri.hr, isamar@sfsb.hr,gsimun@sfsb.hr, pekon@sfsb.hr
}

\begin{abstract}
Investigation of weldability by thermal cycle simulation of welding is an accelerated testing procedure that provides quantitative indicators of weldability in the heat-affected zone of the welded joint. This paper presents the research into weldability by weld thermal cycle simulation performed in single and double passes on the Smitweld 1405 simulator. Thermal cycle simulation of welding significantly shortens the process of selecting optimal welding parameters and attesting the welding procedure, and it also reduces total costs of weldability testing. The data obtained by this weldability testing method are repeatable and verifiable, so they can be used with sufficient reliability in selection of optimal welding parameters and in attesting of welding procedures.

(Received in February 2020, accepted in May 2020. This paper was with the authors 1 month for 1 revision.)
\end{abstract}

Key words: Weldability, Weld Thermal Cycle Simulation, Smitweld 1405, Heat-Affected Zone

\section{INTRODUCTION}

Welding ranks highly among industrial processes and involves more scientific principles and variables than those involved in any other industrial process [1]. It includes a wide range of variables such as time, temperature, electrode, pulse frequency, power input, welding speed etc. that influence the eventual properties of the weld metal $[2,3]$. During the welding process there is a tendency to achieve optimal welding parameters in order to control the heat transfer and residual stresses in the welded joint. The experimental method and the modelling, estimation and simulation methods are used to obtain optimal welding parameters [4-7].

Experimental research is the most significant method of weldability testing because it provides qualitative and quantitative indicators of weldability in real welding conditions or in conditions that are as close as possible to real welding conditions. Experimental testing of weldability can be carried out in a workshop or in a laboratory. Although the attestation follows the final testing of material weldability, it can be said that the weldability test also refers to any investigation of welded joint properties and comparison with the properties of the base material $[8,9]$. As welding engineers aim to obtain a valid welding attest or a highquality welding technology as quickly as possible, they often use the weld thermal cycle simulation as an experimental method. By applying this method, it is possible to "produce" any point in the heat-affected zone and then test it to achieve the least weakening of the base material caused by welding [10]. Hardness and impact energy are usually tested after the weld thermal cycle simulation. It is also possible to test other mechanical properties of individual points in the welded joint or to run some other tests, such as testing of the microstructure of heat-cycled points, testing of susceptibility to corrosion after controlled heat treatment of samples, etc.). There are different types of laboratory equipment used for weld thermal cycle simulation. Tests are usually carried out on the Gleeble, Thermorestor and Smitweld simulators. These devices can be used both for testing of material weldability and for testing of material itself (obtaining TTT diagrams, examining effects of subsequent heat treatment of material, etc.) $[11,12]$. 
This paper presents the results of single-pass and double-pass weld thermal cycle simulation of high-strength steel S960QL on the Smitweld 1405 simulator.

\section{SIMULATION OF SINGLE-PASS AND MULTI-PASS WELDING}

Weld thermal cycle simulator enables single-pass and multi-pass thermal cycling. In tempered materials, single-pass thermal cycling (Fig. 1 a) facilitates greater hardness values in the heataffected zone (HAZ) along the fusion line. In some parts of HAZ, this method can be used to investigate locations where significant weakening of the base material is expected due to welding. In such cases, the testing of mechanical properties (hardness, impact energy) follows the thermal cycle simulation [13]. Simulation of the single-pass HAZ enables detection of the weakest point in the welded joint, thus representing a relatively faster and extremely useful method of studying relevant structural changes in HAZ. Results obtained with the single-pass simulation cannot be compared with multi-pass welding, so it is considered that the tests required for steel and welding process classification have to be carried out by using the multipass welding simulation [14-17]. Multi-pass welding is more common in practice, so the simulation of the thermal cycle is performed in two or more passes. Fig. $1 \mathrm{~b}$ shows the weld thermal cycle simulation in two passes, where the impact of both passes is clearly seen (including the structural transformations at heating and cooling). Strictness of either singlepass of multi-pass simulation of the weld thermal cycle depends on the material that is being tested (i.e. welded). In both cases, mechanical properties and microstructure of the thermally cycled samples are investigated and then compared with the data obtained within tests of the real-welded samples. This procedure significantly shortens the duration of testing on realwelded samples, and it also affects the lowering of costs connected with testing of weldability and obtaining an attest of the welding procedure [18, 19].
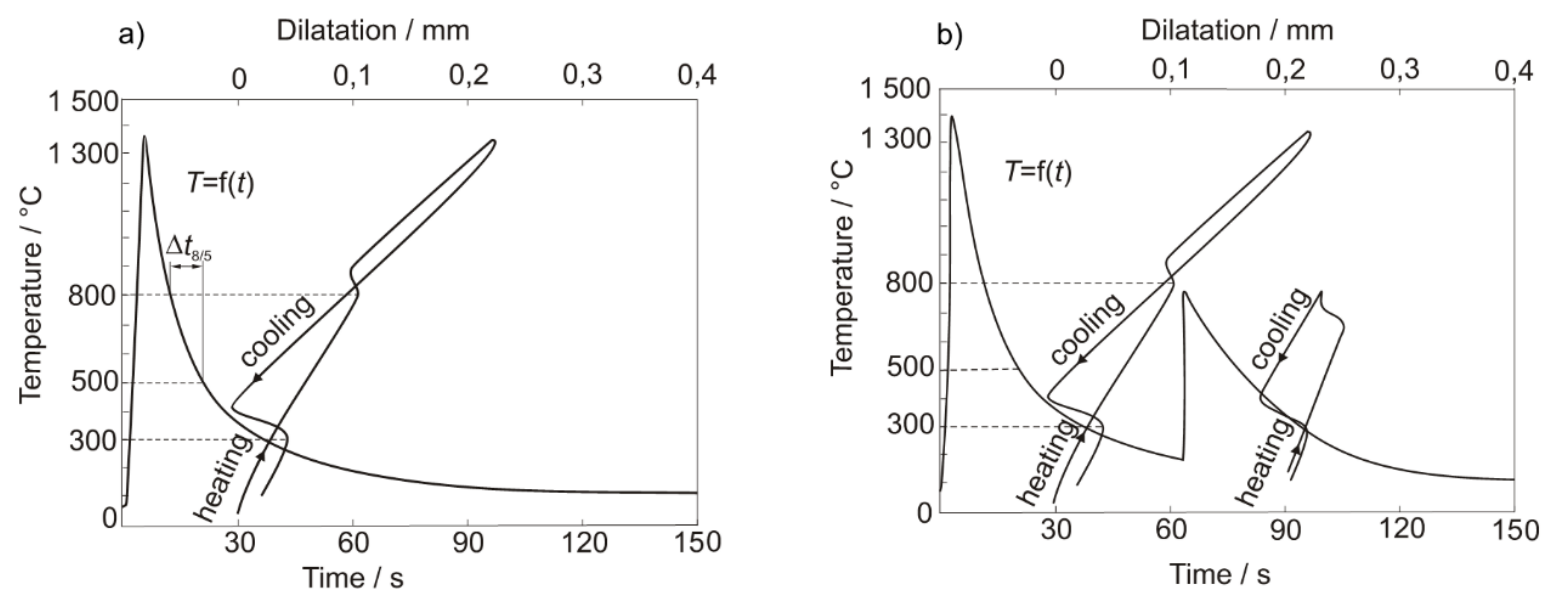

Figure 1: Single-pass (a) and double-pass (b) simulation of the weld thermal cycle $t_{8 / 5}$.

The coarse grain microstructure of HAZ is formed in the thermal conditions presented in Fig. 1 a. The coarse grain microstructure of HAZ develops during the first thermal cycle, as shown in Fig. 1 a, when the temperature reaches above $1350^{\circ} \mathrm{C}$, and then it breaks into small pieces during the influence of the second thermal cycle when the material is heated to $780^{\circ} \mathrm{C}$, which is between $\mathrm{A}_{\mathrm{c} 1}$ and $\mathrm{A}_{\mathrm{c} 3}[20,21]$.

Fig. $1 \mathrm{~b}$ shows a simulation of the thermal cycle of the subsequent pass at a point slightly off the fusion line of the second pass, where the temperature reached $980{ }^{\circ} \mathrm{C}$. There is also recorded dilatation curve, which serves to detect the start and the end of transformation while heating and cooling. In the example shown in the above-mentioned figure, as based on the output dendritic microstructure of a single-pass weld, there is the generated double-pass weld microstructure in which the thermal cycle temperature exceeded the $A_{c 3}$ temperature. Due to 
not so high temperature of the second thermal cycle, the austenite of that pattern could not become quite homogeneous. In this case, the austenitization of the material generated by the first thermal cycle could not be fully achieved [22, 23].

The Smitweld 1405 weld thermal cycle simulator is a computer-controlled system that enables heating and cooling of a test tube within a thermal cycle of a randomly selected point in the heat-affected zone (HAZ), followed by testing of mechanical properties or microstructure of the thermally simulated tube. Fig. 2 presents the Smitweld 1405 in service.

Figs. $3 \mathrm{a}$ and $3 \mathrm{~b}$ show dimensions of specimens for thermal cycle simulation according to the Smitweld method with indirect (a) and direct (b) cooling.
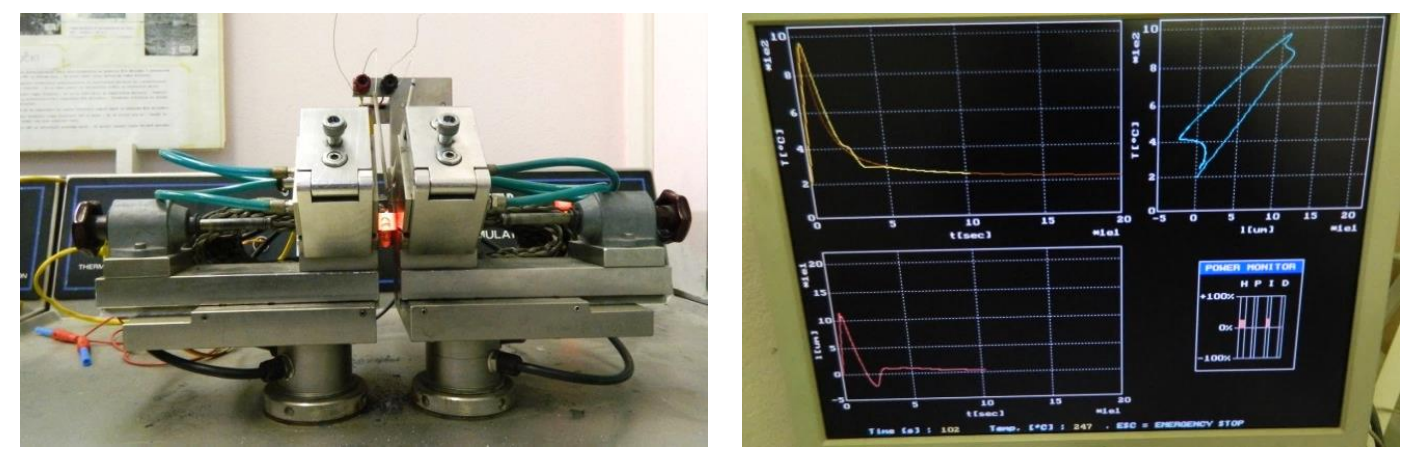

Figure 2: Simulation of fine grain HAZ material on specimen $11 \times 11 \times 57 \mathrm{~mm}$.

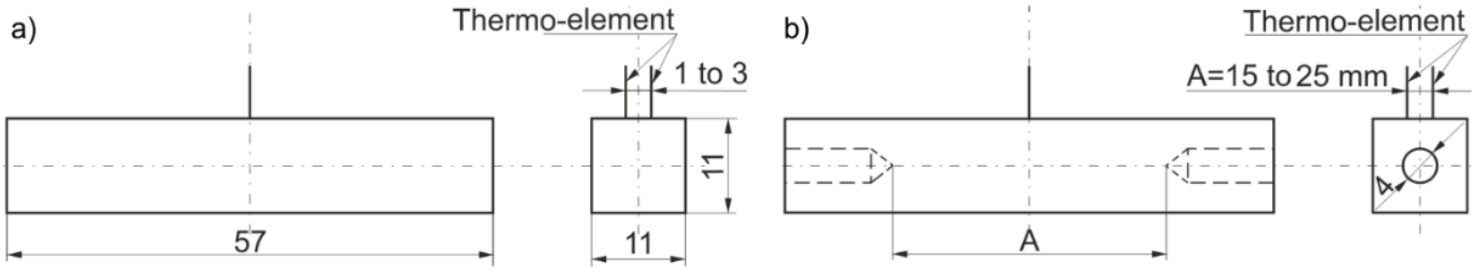

Figure 3: Dimensions of thermal cycle specimens according to the Smitweld TCS 1405 method, in case of indirect cooling (a) and in case of indirect and additional direct cooling by water (b).

\section{MATERIALS AND METHODS}

Preliminary research was performed on the thermal cycle simulator and determined that there is not enough information about the effect of cooling time from $800{ }^{\circ} \mathrm{C}$ to $500{ }^{\circ} \mathrm{C}\left(t_{8 / 5}\right)$, i.e. about the effect of cooling speed on the hardness and toughness of the improved microalloyed high strength steel S960QL. It is important to point out the effect of cooling speed on the hardness and toughness of the single-pass and double-pass weld on the mentioned steel.

Over the past period, the authors applied the weld thermal cycle simulation in testing of weldability of different materials (micro-alloyed steels Nioval 50, TStE 420, high-strength steels S1100QL, as well as T/P 91, T/P 92, etc.).

Within this research, the experiment plans determined that the weld thermal cycle simulation would be performed in single pass and double pass.

Table I overviews the chemical composition and mechanical properties of the tested material.

Single-pass simulation of the thermal cycle was carried out at the maximum temperature of $600,700,800,900,1100$ and $1350{ }^{\circ} \mathrm{C}$. Retention at the maximum temperature was 0.5 seconds, followed by cooling time $t_{8 / 5}$, as shown in Table II. The samples were cooled to less than $150^{\circ} \mathrm{C}$.

When simulating the thermal cycle of welding in two passes, the maximum temperature of the first cycle was $1350^{\circ} \mathrm{C}$, with a retention period at a maximum temperature of 0.5 seconds. The maximum temperatures of the second welding cycle were 600, 700, 800, 900, 1100 and 
$1350{ }^{\circ} \mathrm{C}$. Retention at the maximum temperature was 0.5 seconds, followed by cooling time $t_{8 / 5}$, also shown in Table II. The samples were cooled to less than $150^{\circ} \mathrm{C}$.

Table I: Chemical composition and mechanical properties of the S960QL steel [24].

\begin{tabular}{|c|c|c|c|c|c|c|c|c|c|c|c|c|}
\hline \multirow{3}{*}{ Steel } & \multicolumn{12}{|c|}{ Chemical composition in mass $(\%)$} \\
\hline & $\begin{array}{c}\mathrm{C} \\
\max . \\
0.20\end{array}$ & $\begin{array}{c}\mathrm{Si} \\
\max . \\
0.80\end{array}$ & $\begin{array}{l}\mathrm{Mn} \\
\max . \\
1.70\end{array}$ & $\begin{array}{c}\mathrm{P} \\
\max . \\
0.02\end{array}$ & $\begin{array}{c}\mathrm{S} \\
\max . \\
0.01\end{array}$ & $\begin{array}{c}\mathrm{Cr} \\
\max . \\
1.50\end{array}$ & $\begin{array}{l}\text { Mo } \\
\max . \\
0.70\end{array}$ & $\begin{array}{c}\mathrm{Ni} \\
-\end{array}$ & $\begin{array}{c}\mathrm{Nb} \\
-\end{array}$ & $\begin{array}{l}\mathrm{V} \\
-\end{array}$ & $\begin{array}{c}\mathrm{Cu} \\
-\end{array}$ & $\begin{array}{c}\mathrm{Ti} \\
-\end{array}$ \\
\hline & 0.17 & 0.47 & 1.42 & 0.008 & 0.003 & 0.59 & 0.56 & 0.79 & 0.02 & 0.05 & 0.03 & 0.005 \\
\hline \multirow{5}{*}{$\begin{array}{c}\text { S } 960 \mathrm{QL} \\
\text { case hardened } \\
\text { 3-50 mm diameter }\end{array}$} & \multicolumn{12}{|c|}{ Mechanical properties at standard room temperature } \\
\hline & \multicolumn{3}{|c|}{$\begin{array}{c}\text { Yield strength } \\
R_{p 0,2} \text { min. } 960 \mathrm{MPa} \\
\end{array}$} & \multicolumn{3}{|c|}{$\begin{array}{c}\text { Tensile strength } \\
R m \quad 980-1150 \mathrm{MPa}\end{array}$} & \multicolumn{6}{|c|}{$\begin{array}{l}\text { Elongation break } \\
A_{5} \% \text { min. } 10\end{array}$} \\
\hline & \multicolumn{3}{|c|}{1020} & \multicolumn{3}{|c|}{1080} & \multicolumn{6}{|c|}{16} \\
\hline & \multicolumn{12}{|c|}{ Impact toughness, $\mathrm{KV}$ in $\mathrm{J}$ at $20^{\circ} \mathrm{C}, 0^{\circ} \mathrm{C},-20^{\circ} \mathrm{C}$ and $-40^{\circ} \mathrm{C}$, longitudinally } \\
\hline & \multicolumn{12}{|c|}{ min. $50 \mathrm{~J}, \min .40 \mathrm{~J}$ and $\min .30 \mathrm{~J}$ according to data [12], testing results: $162 \mathrm{~J}, 158 \mathrm{~J}, 76 \mathrm{~J}$ and $58 \mathrm{~J}$} \\
\hline
\end{tabular}

Table II: Parameters at single-pass simulation and double-pass simulation of the thermal cycle.

\begin{tabular}{|c|c|c|c|c|}
\hline $\begin{array}{c}T_{\text {max. }},{ }^{\circ} \mathrm{C} \\
\text { default }\end{array}$ & $v_{\text {heating }}$ & $t_{\text {keeping }}$ & $\begin{array}{c}t_{8 / 5} \\
t_{5 / 3 *}\end{array}$ & $T_{\text {colling }}$ \\
\hline 600 & $200^{\circ} \mathrm{C} / \mathrm{s}$ & $0.5 \mathrm{~s}$ & $28.2^{*}$ & $<150^{\circ} \mathrm{C}$ \\
\hline 700 & $200^{\circ} \mathrm{C} / \mathrm{s}$ & $0.5 \mathrm{~s}$ & $28.2^{*}$ & $<150^{\circ} \mathrm{C}$ \\
\hline 800 & $200^{\circ} \mathrm{C} / \mathrm{s}$ & $0.5 \mathrm{~s}$ & 10 & $<150^{\circ} \mathrm{C}$ \\
\hline 900 & $200^{\circ} \mathrm{C} / \mathrm{s}$ & $0.5 \mathrm{~s}$ & 10 & $<150^{\circ} \mathrm{C}$ \\
\hline 1100 & $200^{\circ} \mathrm{C} / \mathrm{s}$ & $0.5 \mathrm{~s}$ & 10 & $<150^{\circ} \mathrm{C}$ \\
\hline 1350 & $200^{\circ} \mathrm{C} / \mathrm{s}$ & $0.5 \mathrm{~s}$ & 10 & $<150^{\circ} \mathrm{C}$ \\
\hline
\end{tabular}

\section{RESULTS AND DISCUSSION}

The Table III contains data of the measured parameters for the single-pass simulation, and the Table IV presents the measured parameters of the double-pass simulation.

Table III: Measured parameters of the single-pass simulation.

\begin{tabular}{|c|c|c|c|}
\hline $\begin{array}{l}T_{\max ,} \\
{ }^{\circ} \mathrm{C} \text { really }\end{array}$ & $\begin{array}{c}\Delta t_{8 / 5}, \Delta t_{5 / 3} * \\
\text { s really }\end{array}$ & $\overline{H V} 10$ & $\overline{K_{v}}, J$ \\
\hline 605.6 & $29.5^{*}$ & \multirow{6}{*}{351} & \multirow{6}{*}{181} \\
\hline 604.2 & $29.4 *$ & & \\
\hline 605.6 & $28.3^{*}$ & & \\
\hline 607.2 & $28.5^{*}$ & & \\
\hline 610.5 & $28.3^{*}$ & & \\
\hline 610.5 & $28.3^{*}$ & & \\
\hline 712.5 & $29.0^{*}$ & \multirow{6}{*}{350} & \multirow{6}{*}{180} \\
\hline 718.8 & $29.0^{*}$ & & \\
\hline 739.5 & $27.6^{*}$ & & \\
\hline 713.4 & $26.4 *$ & & \\
\hline 717.1 & $28.2^{*}$ & & \\
\hline 716.8 & $28.8^{*}$ & & \\
\hline 824.0 & 10.8 & \multirow{6}{*}{320} & \multirow{6}{*}{82} \\
\hline 811.2 & 11.5 & & \\
\hline 829.2 & 11.1 & & \\
\hline 816.4 & 11.1 & & \\
\hline 811.2 & 11.3 & & \\
\hline 813.5 & 11.3 & & \\
\hline
\end{tabular}

\begin{tabular}{|c|c|c|c|}
\hline $\begin{array}{c}T_{\max ,}, \\
{ }^{\circ} \mathrm{C} \text { really }\end{array}$ & $\begin{array}{c}\Delta t_{8 / 5}, \Delta t_{5 / 3}{ }^{*} \\
\text { s really }\end{array}$ & $\overline{H V} 10$ & $\overline{K_{v}}, J$ \\
\hline 926.9 & 10.7 & \multirow{6}{*}{316} & \multirow{6}{*}{137} \\
\hline 919.9 & 10.8 & & \\
\hline 913.8 & 10.8 & & \\
\hline 913.4 & 10.5 & & \\
\hline 927.6 & 10.8 & & \\
\hline 913.2 & 10.8 & & \\
\hline 1121.1 & 10.8 & \multirow{6}{*}{375} & \multirow{6}{*}{177} \\
\hline 1111.8 & 10.8 & & \\
\hline 1116.5 & 10.8 & & \\
\hline 1131.2 & 10.8 & & \\
\hline 1123.3 & 10.8 & & \\
\hline 1110.9 & 10.8 & & \\
\hline 1363.1 & 9.5 & \multirow{6}{*}{410} & \multirow{6}{*}{109} \\
\hline 1359.2 & 9.8 & & \\
\hline 1360.8 & 9.8 & & \\
\hline 1358.7 & 10.1 & & \\
\hline 1359.0 & 10.3 & & \\
\hline 1354.0 & 10.2 & & \\
\hline
\end{tabular}


Table IV: Measured parameters of double-pass simulation.

\begin{tabular}{|c|c|c|c|c|}
\hline $\begin{array}{c}T_{\max .1}, \\
T_{\max .2}, \\
{ }^{\circ} \mathrm{C} \text { really }\end{array}$ & $\begin{array}{c}\Delta t_{8 / 5} \\
\Delta t_{5 / 3} * \\
\text { s really }\end{array}$ & $\begin{array}{c}T_{\mathrm{A}} \\
\text { default }\end{array}$ & $\overline{H V} 10$ & $\overline{K_{v}}, J$ \\
\hline $\begin{array}{l}1354.8 / \\
607.0^{\circ} \mathrm{C}\end{array}$ & $\begin{array}{l}\Delta t_{8 / 5}=9.3, \\
\Delta t_{5 / 3}=29.2^{*}\end{array}$ & $\begin{array}{l}1350 / 0.5 \mathrm{~s} \\
600 / 0.5 \mathrm{~s}\end{array}$ & \multirow{4}{*}{351} & \multirow{4}{*}{181} \\
\hline $\begin{array}{l}1354.3 / \\
605.9^{\circ} \mathrm{C}\end{array}$ & $\begin{array}{l}\Delta t_{8 / 5}=9.2, \\
\Delta t_{5 / 3}=29.1^{*}\end{array}$ & $\begin{array}{l}1350 / 0.5 \mathrm{~s} \\
600 / 0.5 \mathrm{~s}\end{array}$ & & \\
\hline $\begin{array}{l}1370.8 / \\
608.2^{\circ} \mathrm{C}\end{array}$ & $\begin{array}{l}\Delta t_{8 / 5}=9.7, \\
\Delta t_{5 / 3}=29.4^{*}\end{array}$ & $\begin{array}{l}1350 / 0.5 \mathrm{~s} \\
600 / 0.5 \mathrm{~s}\end{array}$ & & \\
\hline $\begin{array}{l}1364.0 / \\
610.5^{\circ} \mathrm{C}\end{array}$ & $\begin{array}{l}\Delta t_{8 / 5}=9.7, \\
\Delta t_{5 / 3}=29.4^{*}\end{array}$ & $\begin{array}{l}1350 / 0.5 \mathrm{~s} \\
600 / 0.5 \mathrm{~s}\end{array}$ & & \\
\hline $\begin{array}{l}1360.2 / \\
707.0^{\circ} \mathrm{C}\end{array}$ & $\begin{array}{l}\Delta t_{8 / 5}=9.1, \\
\Delta t_{5 / 3}=28.2^{*}\end{array}$ & $\begin{array}{l}1350 / 0.5 \mathrm{~s} \\
700 / 0.5 \mathrm{~s}\end{array}$ & \multirow{4}{*}{350} & \multirow{4}{*}{180} \\
\hline $\begin{array}{l}1366.2 / \\
704.0^{\circ} \mathrm{C}\end{array}$ & $\begin{array}{l}\Delta t_{8 / 5}=8.7, \\
\Delta t_{5 / 3}=28.2^{*}\end{array}$ & $\begin{array}{l}1350 / 0.5 \mathrm{~s} \\
700 / 0.5 \mathrm{~s}\end{array}$ & & \\
\hline $\begin{array}{l}1356.0 / \\
717.0^{\circ} \mathrm{C}\end{array}$ & $\begin{array}{l}\Delta t_{8 / 5}=9.2, \\
\Delta t_{5 / 3}=29.1^{*}\end{array}$ & $\begin{array}{l}1350 / 0.5 \mathrm{~s} \\
700 / 0.5 \mathrm{~s}\end{array}$ & & \\
\hline $\begin{array}{l}1360.0 / \\
719.0^{\circ} \mathrm{C}\end{array}$ & $\begin{array}{l}\Delta t_{8 / 5}=9.7, \\
\Delta t_{5 / 3}=28.8^{*}\end{array}$ & $\begin{array}{l}1350 / 0.5 \mathrm{~s} \\
700 / 0.5 \mathrm{~s}\end{array}$ & & \\
\hline $\begin{array}{l}1371.5 / \\
823.7^{\circ} \mathrm{C}\end{array}$ & $\begin{array}{l}\Delta t_{18 / 5}=9.0 \\
\Delta t_{28 / 5}=10.1\end{array}$ & $\begin{array}{l}1350 / 0.5 \mathrm{~s} \\
800 / 0.5 \mathrm{~s}\end{array}$ & \multirow{4}{*}{415} & \multirow{4}{*}{87} \\
\hline $\begin{array}{l}1358.2 / \\
814.1^{\circ} \mathrm{C}\end{array}$ & $\begin{array}{l}\Delta t_{18 / 5}=8.9, \\
\Delta t_{28 / 5}=10.3\end{array}$ & $\begin{array}{l}1350 / 0.5 \mathrm{~s} \\
800 / 0.5 \mathrm{~s}\end{array}$ & & \\
\hline $\begin{array}{l}1371.5 / \\
821.7^{\circ} \mathrm{C}\end{array}$ & $\begin{array}{l}\Delta t_{18 / 5}=9.3 \\
\Delta t_{28 / 5}=10.2\end{array}$ & $\begin{array}{l}1350 / 0.5 \mathrm{~s} \\
800 / 0.5 \mathrm{~s}\end{array}$ & & \\
\hline $\begin{array}{l}1354.5 / \\
822.5^{\circ} \mathrm{C}\end{array}$ & $\begin{array}{l}\Delta t_{18 / 5}=8.3 \\
\Delta t_{28 / 5}=10.1\end{array}$ & $\begin{array}{l}1350 / 0.5 \mathrm{~s} \\
800 / 0.5 \mathrm{~s}\end{array}$ & & \\
\hline
\end{tabular}

\begin{tabular}{|c|c|c|c|c|}
\hline $\begin{array}{c}T_{\max .1}, \\
T_{\max .2}, \\
{ }^{\circ} \mathrm{C} \text { really }\end{array}$ & $\begin{array}{c}\Delta t_{8 / 5} \\
\Delta t_{5 / 3}{ }^{*} \\
\text { s really }\end{array}$ & $\begin{array}{c}T_{\mathrm{A}} \\
\text { default }\end{array}$ & $\overline{H V} 10$ & $\overline{K_{v}}, J$ \\
\hline $\begin{array}{l}1359.2 / \\
918.5^{\circ} \mathrm{C}\end{array}$ & $\begin{array}{l}\Delta t_{18 / 5}=8.2, \\
\Delta t_{28 / 5}=11.0\end{array}$ & $\begin{array}{l}1350 / 0.5 \mathrm{~s} \\
900 / 0.5 \mathrm{~s}\end{array}$ & \multirow{4}{*}{385} & \multirow{4}{*}{125} \\
\hline $\begin{array}{l}1358.1 / \\
921.8^{\circ} \mathrm{C}\end{array}$ & $\begin{array}{l}\Delta t_{18 / 5}=8.5, \\
\Delta t_{28 / 5}=10.8\end{array}$ & $\begin{array}{l}1350 / 0.5 \mathrm{~s} \\
900 / 0.5 \mathrm{~s}\end{array}$ & & \\
\hline $\begin{array}{l}1356.1 / \\
918.5^{\circ} \mathrm{C}\end{array}$ & $\begin{array}{l}\Delta t_{18 / 5}=8.0, \\
\Delta t_{28 / 5}=10.8\end{array}$ & $\begin{array}{l}1350 / 0.5 \mathrm{~s} \\
900 / 0.5 \mathrm{~s}\end{array}$ & & \\
\hline $\begin{array}{l}1371.5 / \\
935.1^{\circ} \mathrm{C}\end{array}$ & $\begin{array}{l}\Delta t_{18 / 5}=8.0, \\
\Delta t_{28 / 5}=10.5\end{array}$ & $\begin{array}{l}1350 / 0.5 \mathrm{~s} \\
900 / 0.5 \mathrm{~s}\end{array}$ & & \\
\hline $\begin{array}{l}1359.8 / \\
1123.0^{\circ} \mathrm{C}\end{array}$ & $\begin{array}{l}\Delta t_{18 / 5}=8.2, \\
\Delta t_{28 / 5}=9.3\end{array}$ & $\begin{array}{l}1350 / 0.5 \mathrm{~s} \\
1100 / 0.5 \mathrm{~s}\end{array}$ & \multirow{4}{*}{375} & \multirow{4}{*}{131} \\
\hline $\begin{array}{l}1379.2 / \\
1136.5^{\circ} \mathrm{C}\end{array}$ & $\begin{array}{l}\Delta t_{18 / 5}=8.0 \\
\Delta t_{28 / 5}=9.4\end{array}$ & $\begin{array}{l}1350 / 0.5 \mathrm{~s} \\
1100 / 0.5 \mathrm{~s}\end{array}$ & & \\
\hline $\begin{array}{l}1357.5 / \\
1135.0^{\circ} \mathrm{C}\end{array}$ & $\begin{array}{l}\Delta t_{18 / 5}=8.0 \\
\Delta t_{28 / 5}=8.8\end{array}$ & $\begin{array}{l}1350 / 0.5 \mathrm{~s} \\
1100 / 0.5 \mathrm{~s}\end{array}$ & & \\
\hline $\begin{array}{l}1359.8 / \\
1123.0^{\circ} \mathrm{C}\end{array}$ & $\begin{array}{l}\Delta t_{18 / 5}=8.9, \\
\Delta t_{28 / 5}=9.8\end{array}$ & $\begin{array}{l}1350 / 0.5 \mathrm{~s} \\
1100 / 0.5 \mathrm{~s}\end{array}$ & & \\
\hline $\begin{array}{l}1357.7 / \\
1366.8^{\circ} \mathrm{C}\end{array}$ & $\begin{array}{l}\Delta t_{18 / 5}=9.0 \\
\Delta t_{28 / 5}=9.0\end{array}$ & $\begin{array}{l}1350 / 0.5 \mathrm{~s} \\
1350 / 0.5 \mathrm{~s}\end{array}$ & \multirow{4}{*}{421} & \multirow{4}{*}{90} \\
\hline $\begin{array}{l}1365.5 / \\
1369.7^{\circ} \mathrm{C}\end{array}$ & $\begin{array}{l}\Delta t_{18 / 5}=8.2, \\
\Delta t_{28 / 5}=8.5\end{array}$ & $\begin{array}{l}1350 / 0.5 \mathrm{~s} \\
1350 / 0.5 \mathrm{~s}\end{array}$ & & \\
\hline $\begin{array}{l}1372.6 / \\
1370.2^{\circ} \mathrm{C}\end{array}$ & $\begin{array}{l}\Delta t_{18 / 5}=9.6 \\
\Delta t_{28 / 5}=8.8\end{array}$ & $\begin{array}{l}1350 / 0.5 \mathrm{~s} \\
1350 / 0.5 \mathrm{~s}\end{array}$ & & \\
\hline $\begin{array}{l}1350.0 / \\
1350.0{ }^{\circ} \mathrm{C}\end{array}$ & $\begin{array}{l}\Delta t_{18 / 5}=9.7, \\
\Delta t_{28 / 5}=8.1\end{array}$ & $\begin{array}{l}1350 / 0.5 \mathrm{~s} \\
1350 / 0.5 \mathrm{~s}\end{array}$ & & \\
\hline
\end{tabular}

whereas:

$v_{\text {heating }}$ - heating speed, ${ }^{\circ} \mathrm{C} / \mathrm{s}$,

$T_{\text {cooling }}$ - measured temperature at the end of welding cycle (cooling), ${ }^{\circ} \mathrm{C}$,

$T_{\max } \quad$ maximum temperature of the thermal cycle, ${ }^{\circ} \mathrm{C}$,

$T_{\mathrm{A}} \quad$ - temperature of austenitization, ${ }^{\circ} \mathrm{C}$,

$\Delta t_{8 / 5} \quad$ - cooling time from 800 to $500{ }^{\circ} \mathrm{C}$,

$\Delta t_{5 / 3} \quad$ - cooling time from 500 to $300^{\circ} \mathrm{C}$,

$\overline{\mathrm{HV}} 10$ - average value of 4 measurements,

$\overline{K_{v}} \quad-$ mean value of the impact energy -4 measurements.

Figs. 4 and 5 show the results of the HV10 hardness testing on samples that were simulated in single and in double pass welding. The base material hardness HV10 was between 348 and 350. Single-pass simulation did not cause changes in hardness at maximum thermal cycle temperatures of 600 and $700{ }^{\circ} \mathrm{C}$. At maximum thermal cycle temperatures of 800 and $900{ }^{\circ} \mathrm{C}$, there was a slight decrease in hardness, which mean values were $320 \mathrm{HV}$ and $316 \mathrm{HV}$, respectively. At a maximum thermal cycle temperature of $1100{ }^{\circ} \mathrm{C}$, the hardness value increased to $375 \mathrm{HV}$. Further increase of the maximum thermal cycle temperature to $1350{ }^{\circ} \mathrm{C}$ affected the increase of hardness value to $410 \mathrm{HV}$. The high values of hardness are a result of grain coarsening and the increase of martensite portion in the structure $[25,26]$. 
Thermal cycle simulation in two passes (the first pass $1350{ }^{\circ} \mathrm{C}$, and the second pass $600^{\circ} \mathrm{C}$ and $700^{\circ} \mathrm{C}$ ), did not cause changes in the hardness values after simulation, if compared to the initial values. Thermal cycle (the first pass $1350{ }^{\circ} \mathrm{C}$, the second pass $800^{\circ} \mathrm{C}$ ) resulted in the hardness of $390 \mathrm{HV}$. Within the further thermal cycles (the first pass $1350^{\circ} \mathrm{C}$, and the second pass $900{ }^{\circ} \mathrm{C}$ ) and (the first pass $1350{ }^{\circ} \mathrm{C}$, and the second pass $1100^{\circ} \mathrm{C}$ ), the hardness value decreased to around $370 \mathrm{HV}$. In the last thermal cycle (the first pass $1350^{\circ} \mathrm{C}$, the second pass $1350^{\circ} \mathrm{C}$ ), the hardness value was $407 \mathrm{HV}$.
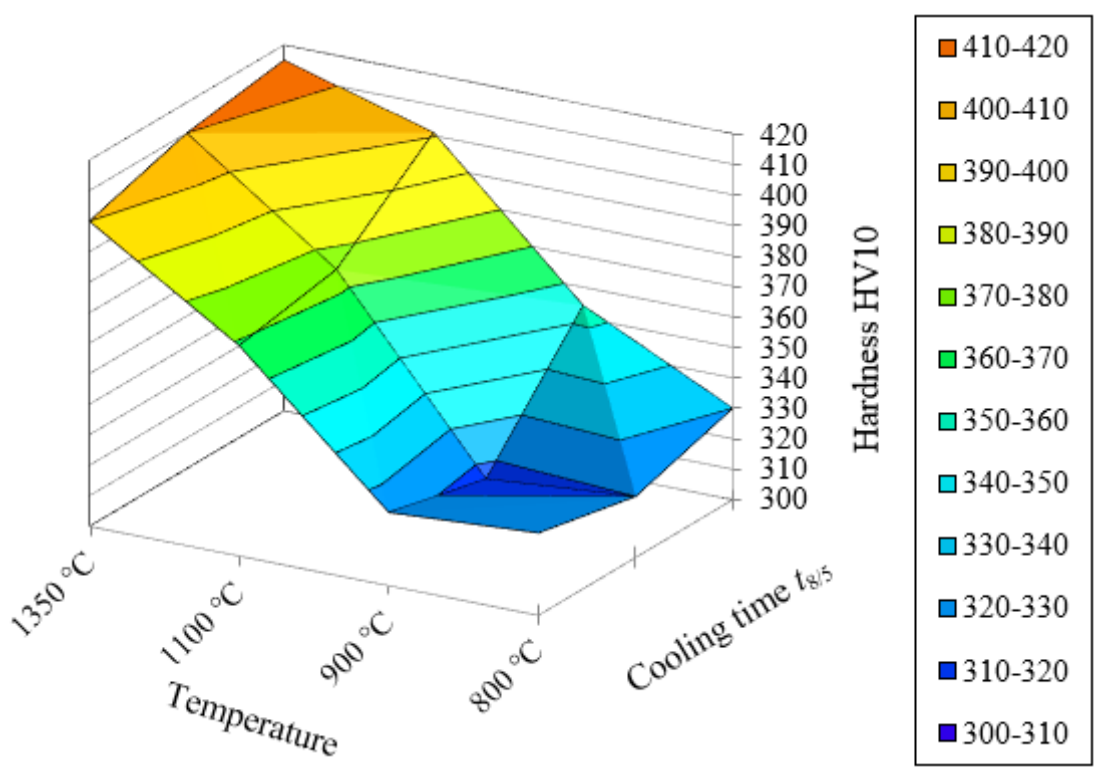

Figure 4: Results of testing the hardness of single-pass simulated specimens with cooling time $t_{8 / 5}=10 \mathrm{~s}$ at a maximum thermal cycle temperature of $1350,1100,900$ and $800^{\circ} \mathrm{C}$.
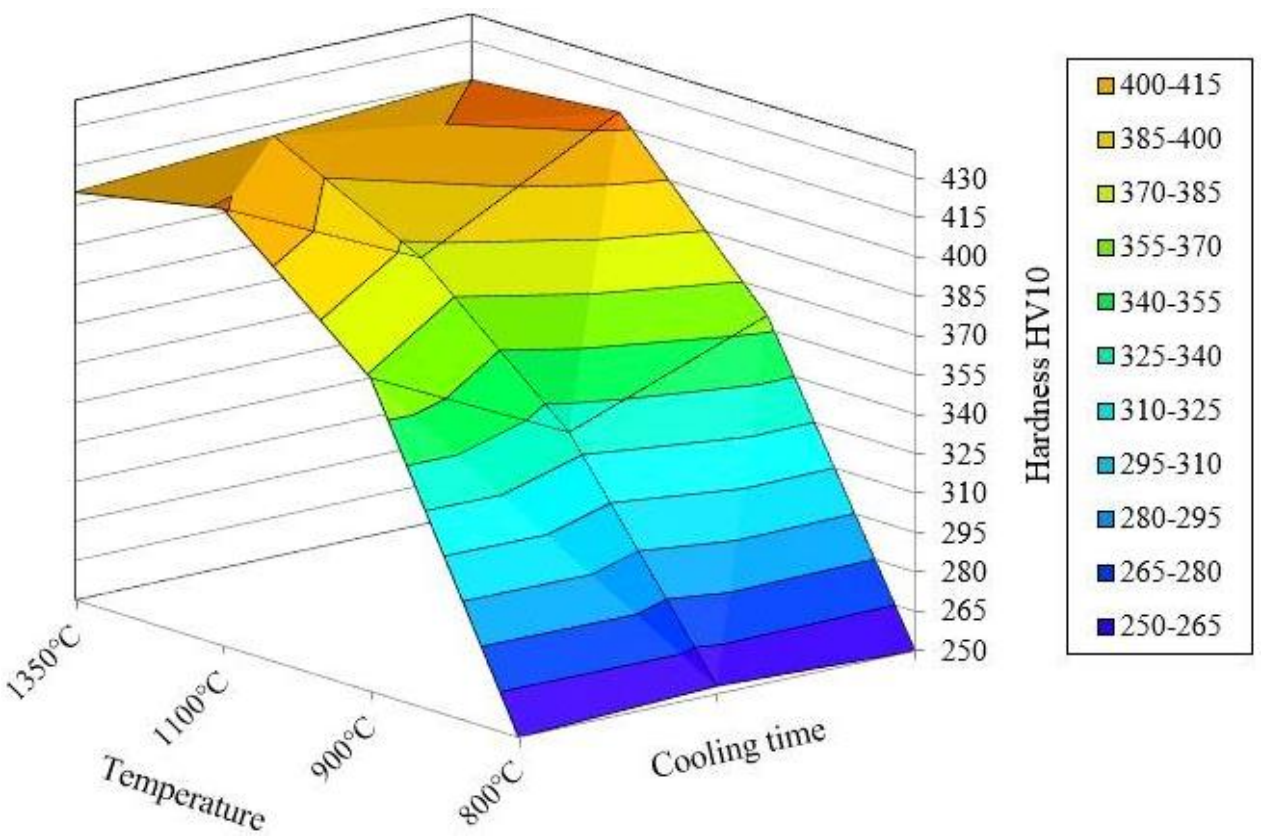

Figure 5: Results of testing the hardness of double-pass simulated specimens with cooling time $t_{8 / 5}=$ $10 \mathrm{~s}$ at a maximum thermal cycle temperature of 1350 (first cycle), 1350, 1100, 900 and $800{ }^{\circ} \mathrm{C}$ (second cycle).

Figs. 6 and 7 present two examples of registered toughness on simulated microstructures when welding the S960QL steel. 
Fig. 6 presents the Charpy toughness of the coarse-grain HAZ being dependent on the maximum thermal cycle temperature. The toughness initially grows along with the increase of the thermal cycle temperature and then it falls. Martensitic microstructure is formed by the fastest cooling. The highest toughness is associated with the presence of a certain share of bainite in martensite. Slower cooling causes more bainite to form and the toughness begins to decrease. The maximum toughness in Fig. 6 corresponds to the partial austenitization of the coarse-grain martensite/bainite microstructure.

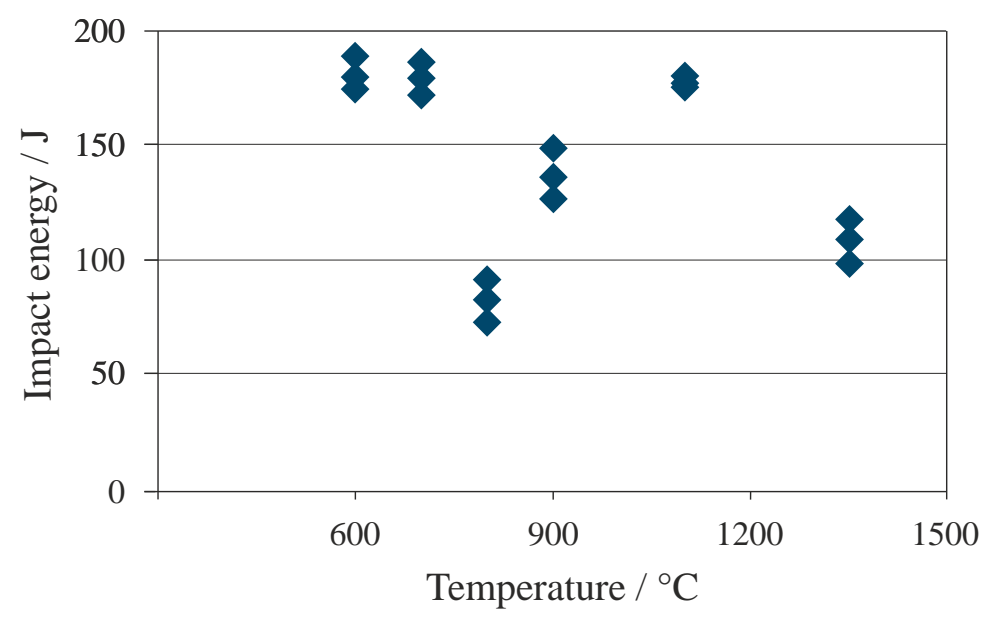

Figure 6: Results of testing the impact energy of single-pass simulated specimens with cooling time $t_{8 / 5}=10 \mathrm{~s}$ at a maximum thermal cycle temperature of $1350,1100,900,800$ and $600^{\circ} \mathrm{C}$.

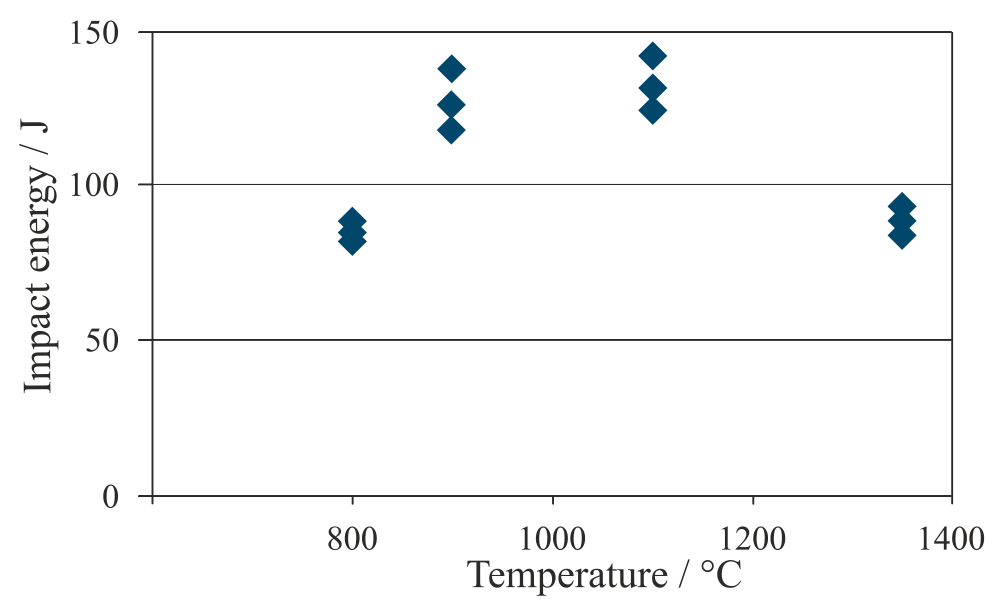

Figure 7: Results of testing the impact energy of double-pass simulated specimens with cooling time $t_{8 / 5}=10 \mathrm{~s}$ at a maximum thermal cycle temperature of $1350^{\circ} \mathrm{C}$ (first cycle) and 1350,1100 , 900 and $800^{\circ} \mathrm{C}$ (second cycle).

Fig. 7 presents the Charpy toughness of HAZ along the fusion line, where the next pass output coarse-grain HAZ takes effect. This HAZ has the highest toughness $\left(1100^{\circ} \mathrm{C}\right)$ after the first pass. Toughness is the lowest when the temperature of the second thermal cycle becomes so high to complete the austenitization. This austenite prior to initial cooling is not sufficiently homogenized. The toughness again significantly increases when the temperature of the second thermal cycle is so high that the austenite becomes homogeneous.

Fig. 8 presents the microstructure of the base material, which is the improved highstrength steel S960QL. This is a fine-grain structure of a tempered martensite with a certain share of bainite, having hardness of $\mathrm{HV} 10=348$. When heating to $1350^{\circ} \mathrm{C}$ and cooling at the cooling time $t_{8 / 5}=10 \mathrm{~s}$, the hardness increases at $\mathrm{HV} 10=410$ due to higher share of martensite and coarsening of grain, which is shown in Fig. 9. 


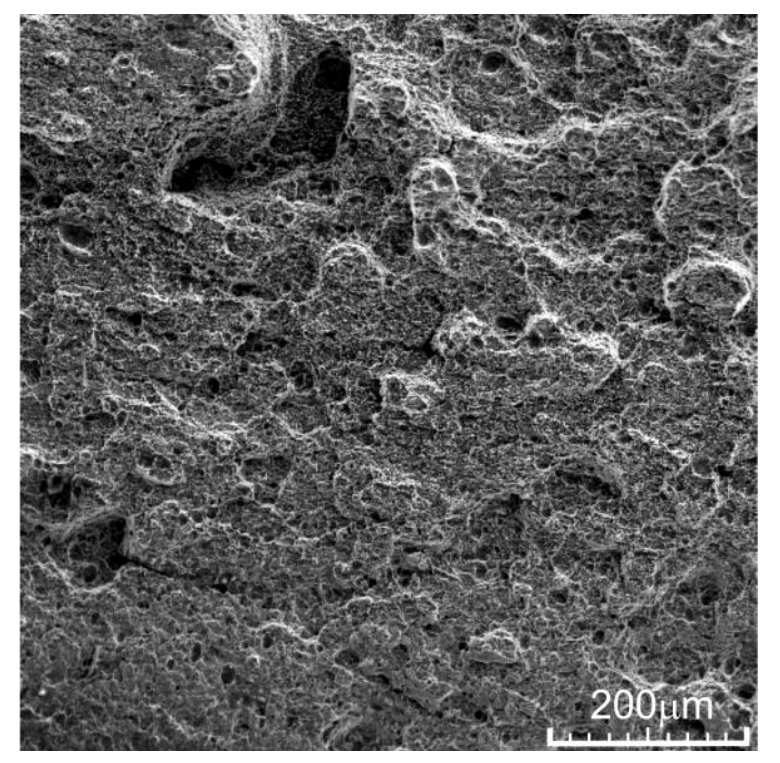

Figure 8: Microstructure of the base material steel S960QL; magnification $200 \times$.

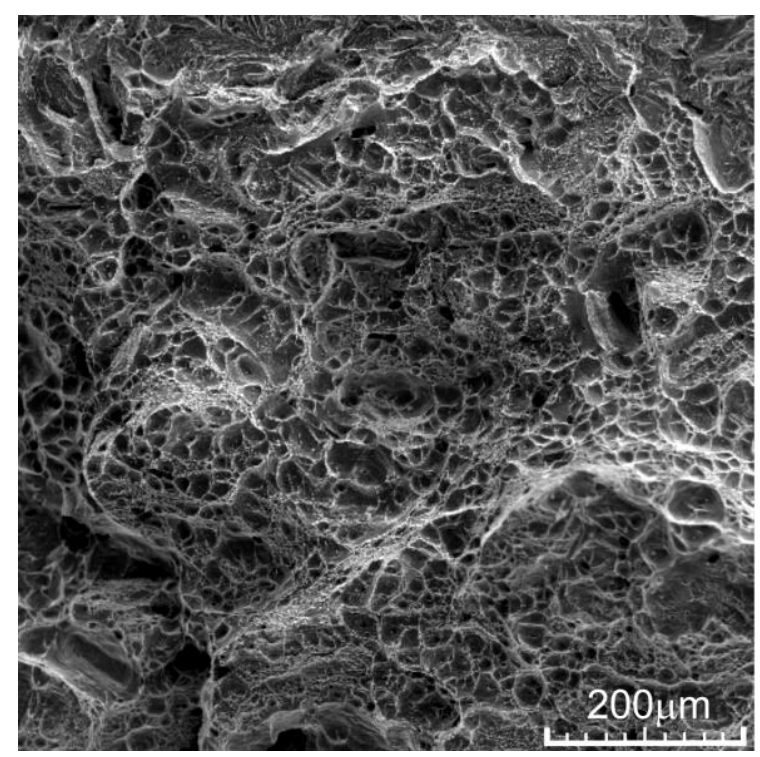

Figure 9: Microstructure of the steel S960QL, maximum temperature of thermal cycle $1350{ }^{\circ} \mathrm{C}$, magnification $200 \times$.

\section{CONCLUSION}

Cooling speed, i.e. cooling time $\Delta t_{8 / 5}$ has significant effect on the properties of the welded joint. Satisfactory relation between hardness and impact energy can be achieved by selecting the appropriate cooling speed. This facilitates creation of the microstructure that is less susceptible to cold cracks.

Single-pass welding simulations usually focus on investigation of thermal cycles with a maximum temperature between $1200^{\circ} \mathrm{C}$ and $1350{ }^{\circ} \mathrm{C}$. The authors of this paper performed researches into thermal cycles with the maximum temperature of 1350 do $1380^{\circ} \mathrm{C}$.

By applying single-pass simulation of thermal cycles, there are satisfactory hardness and microstructure obtained at a temperature of $1100^{\circ} \mathrm{C}$, meaning that the structure is martensitebainite and the hardness is from 365 to $385 \mathrm{HV}$, which guarantees the satisfactory impact energy. 
The highest values of impact energy are related to the fine martensitic grain structure that occurs at a temperature slightly higher than $\mathrm{A}_{\mathrm{c} 3}$, which was in this research $1100{ }^{\circ} \mathrm{C}$. Temperature that is higher than the above mentioned one causes the lowering of the impact energy. Furthermore, maximum impact energy at $1100{ }^{\circ} \mathrm{C}$ reduces hardness. Additional increase of temperature leads to the decrease of impact energy (Figs. 6 and 7), which is then conditioned by the hardness increase (diagram shown in the Figs. 4 and 5).

Welding of the S960QL steel is based on the controlled input of energy during welding process (pre-heating, temperature between passes, heat input achieved by the electric arc, reheating) and strict application of the defined procedure steps, all for the purpose of avoiding cold cracks and other manufacturing faults, and of securing the required properties of the welded joint.

Simulation of weld thermal cycle provides results that can be used to optimize the welding parameters of micro-alloyed high strength steel. These results are useful in real welding environment, as they facilitate assurance of optimal mechanical properties of welded joints in micro-alloyed high strength steels [27-29].

Further research will be focused on investigation of mechanical properties of real samples welded by MAG welding procedure.

\section{REFERENCES}

[1] Ismail, M. I. S.; Afieq, W. M. (2016). Thermal analysis on a weld joint of aluminium alloy in gas metal arc welding, Advances in Production Engineering \& Management, Vol. 11, No. 1, 29-37, doi:10.14743/apem2016.1.207

[2] Talabi, S. I.; Owolabi, O. B.; Adebisi, J. A.; Yahaya, T. (2014). Effect of welding variables on mechanical properties of low carbon steel welded joint, Advances in Production Engineering \& Management, Vol. 9, No. 4, 181-186, doi:10.14743/apem2014.4.186

[3] Duan, B.; Wang, J. C.; Lu, Z. H.; Zhang, G. X.; Zhang, C. H. (2018). Parameter analysis and optimization of the rotating arc NG-GMAW welding process, International Journal of Simulation Modelling, Vol. 17, No. 1, 170-179, doi:10.2507/IJSIMM17(1)CO4

[4] Ogrinec, P.; Čepon, G.; Boltežar, M. (2018). Introduction of welds into the dynamic model of laminated structures, Strojniski vestnik - Journal of Mechanical Engineering, Vol. 64, No. 2, 73 81, doi:10.5545/sv-jme.2017.4915

[5] López-Martínez, E.; Vergara-Hernández, H. J.; Serna, S.; Campillo, B. (2015). Artificial neural networks to estimate the thermal properties of an experimental micro-alloyed steel and their application to the welding thermal analysis, Strojniski vestnik - Journal of Mechanical Engineering, Vol. 61, No. 12, 741-750, doi:10.5545/sv-jme.2015.2610

[6] Koňár, R.; Patek, M. (2017). Numerical simulation of dissimilar weld joint in SYSWELD simulation software, Tehnicki vjesnik - Technical Gazette, Vol. 24, Suppl. 1, 137-142, doi:10.17559/TV-20150513074103

[7] Yunusbaev, N.; Gabitov, I.; Farhatov, M.; Nafikov, M.; Saifullin, R.; Zagirov, I.; Insafuddinov, S. (2019). Perspective method of restoration of autotractor parts by electrocontact welding of powder materials in the magnetic field, Tribology in Industry, Vol. 41, No. 1, 115-125, doi: $10.24874 /$ ti.2019.41.01.13

[8] Raweni, A.; Majstorovic, V.; Sedmak, A.; Tadic, S.; Kirin, S. (2018). Optimization of AA5083 friction stir welding parameters using Taguchi method, Tehnicki vjesnik - Technical Gazette, Vol. 25, No. 3, 861-866, doi:10.17559/TV-20180123115758

[9] Kascak, L.; Mucha, J.; Witkowski, W. (2018). Plastic formed and spot welded joints strength of S350GD+Z steel, Tehnicki vjesnik - Technical Gazette, Vol. 25, No. 6, 1623-1630, doi:10.17559/TV-20170321223648

[10] Scotti, A.; Li, H.; Miranda, R. M. (2014). A round-robin test with thermal simulation of the welding HAZ to draw CCT diagrams: a need for harmonized procedures and microconstituent terminologies, Soldagem \& Inspeção, Vol. 19, No. 3, 279-290, doi:10.1590/0104$\underline{9224 / \text { SI1903.11 }}$ 
[11] Guo, Y. H.; Lin, L.; Zhang, D.; Liu, L.; Lei, M. K. (2018). Microstructure and mechanical properties of heat-affected zone of repeated welding AISI 304N austenitic stainless steel by Gleeble simulator, Metals, Vol. 8, No. 10, Paper 773, 14 pages, doi:10.3390/met8100773

[12] Kardoulaki, E.; Lin, J.; Balint, D.; Farrugia, D. (2014). Investigation of the effects of thermal gradients present in Gleeble high-temperature tensile tests on the strain state for free cutting steel, The Journal of Strain Analysis for Engineering Design, Vol. 49, No. 7, 521-532, doi: $10.1177 / 0309324714531950$

[13] Hildebrand, J.; Werner, F. (2004). Change of structural condition of welded joints between highstrength fine-grained and structural steels, Journal of Civil Engineering and Management, Vol. 10, No. 2, 87-95, doi:10.1080/13923730.2004.9636292

[14] Kulhánek, J.; Tomíčik, P.; Trojan, R.; Juránek, M.; Klaus, P. (2016). Experimental modeling of weld thermal cycle of heat affected zone (HAZ), Metalurgija, Vol. 55, No. 4, 733-736

[15] Celin, R.; Burja, J.; Kosec, G. (2016). A comparison of as-welded and simulated heat affected zone (HAZ) microstructures, Materiali in tehnologije - Materials and Technology, Vol. 50, No. 3, 455-460, doi:10.17222/mit.2016.006

[16] Gáspár, M.; Balogh, A. (2013). GMAW experiments for advanced (Q+T) high strength steels, Production Processes and Systems, Vol. 6, No. 1, 9-24

[17] Konat, L. (2019). Structural aspects of execution and thermal treatment of welded joints of Hardox extreme steel, Metals, Vol. 9, No. 9, Paper 915, 22 pages, doi:10.3390/met9090915

[18] Cruz-Crespo, A.; de Araujo, B. D.; Scotti, A. (2013). Effect of tempering pass on HSLA-80 steel HAZ microstructures, Welding Journal, Vol. 92, No. 10, 304-311

[19] Zhang, Y.-Q.; Zhang, H.-Q.; Li, J.-F.; Liu, W.-M. (2009). Effect of heat input on microstructure and toughness of coarse grain heat-affected zone in $\mathrm{Nb}$ microalloyed HSLA steels, Journal of Iron and Steel Research International, Vol. 16, No. 5, 73-80, doi:10.1016/S1006-706X(10)60014-3

[20] Shanmugam, S.; Ramisetti, N. K.; Misra, R. D. K.; Hartmann, J.; Jansto, S. G. (2008). Microstructure and high strength-toughness combination of a new $700 \mathrm{MPa} \mathrm{Nb}$-microalloyed pipeline steel, Materials Science and Engineering: A, Vol. 478, No. 1-2, 26-37, doi:10.1016/ j.msea.2007.06.003

[21] Shi, Y.; Han, Z. (2008). Effect of weld thermal cycle on microstructure and fracture toughness of simulated heat-affected zone for a $800 \mathrm{MPa}$ grade high strength low alloy steel, Journal of Materials Processing Technology, Vol. 207, No. 1-3, 30-39, doi:10.1016/ j.jmatprotec.2007.12.049

[22] Shome, M.; Mohanty, O. N. (2006). Continuous cooling transformation diagrams applicable to the heat-affected zone of HSLA-80 and HSLA-100 steels, Metallurgical and Materials Transactions A, Vol. 37, No. 7, 2159-2169, doi:10.1007/BF02586136

[23] Gáspár, M.; Balogh, A.; Lukács, J. (2017). Toughness examination of physically simulated S960QL HAZ by a special drilled specimen, Jármai, K.; Bolló, B. (Eds.), Vehicle and Automotive Engineering, Lecture Notes in Mechanical Engineering, Springer, Cham, 469-481, doi: $10.1007 / 978-3-319-51189-4 \quad 40$

[24] Dunđer, M.; Vuherer, T.; Samardžić, I. (2014). Weldability prediction of high strength steel S960QL after weld thermal cycle simulation, Metalurgija, Vol. 53, No. 4, 627-630

[25] Gáspár, M. (2019). Effect of welding heat input on simulated HAZ areas in S960QL high strength steel, Metals, Vol. 9, No. 11, Paper 1226, 14 pages, doi:10.3390/met9111226

[26] Grdun, V.; Godec, B. (2002). Unfavourable micro-constituents in the welded joints of construction steels, Materiali in tehnologije, Vol. 36, No 5, 247-254 (in Slovene)

[27] Attarhal, M. J.; Sattari-Far, I. (2011). Study on welding temperature distribution in thin welded plates experimental measurements and finite element simulation, Journal of Materials Processing Technology, Vol. 211, No. 4, 688-694, doi:10.1016/j.jmatprotec.2010.12.003

[28] Nowicki, J.; Sajek, A.; Matkowski, P. (2016). The influence of welding heat input on the microstructure of joints of S1100QL steel in one-pass welding, Archives of Civil and Mechanical Engineering, Vol. 16, No. 4, 777-783, doi:10.1016/j.acme.2016.05.001

[29] Shome, M.; Gupta, O. P.; Mohanty, O. N. (2004). Effect of simulated thermal cycles on the microstructure of the heat-affected zone in HSLA-80 and HSLA-100 steel plates, Metallurgical and Materials Transactions A, Vol. 35, No. 13, 985-996, doi:10.1007/s11661-004-0025-8 